\title{
"I AM MORE INTERESTED THANYOU KNOW, BILL": THE LIFE AND TIMES OF WILLIAM HENRY DUCKETT JR.
}

STEPHANIE M. BLALOCK AND BRANDON JAMES O’NEIL

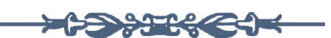

William Henry “Bill” Duckett JR.'s ROLE as Walt Whitman's carriage driver and youthful companion is typically the extent of his portrayal in Whitman biography. Details of the Duckett family history and of Bill's adult life, however, have remained largely shrouded in mystery. As far as Whitman scholarship is concerned, Duckett was practically condemned to spend adulthood in obscurity after falling out of favor with Whitman's disciples and losing touch with the poet once he had moved out of Whitman's Camden home at 328 Mickle Street. Drawing on a combination of digital, archival, and printed materials, this essay aims to trace Bill's past and to uncover previously unknown details about his personal and professional life before, during, and after his friendship with Whitman. Court proceedings, city directories, and digitized newspaper articles enabled us to corroborate information in Whitman's notebooks and his two-way correspondence with Duckett, available on the Walt Whitman Archive. Resources well-known to genealogy enthusiasts and professionals-Ancestry.com, Newspapers.com, and FamilySearch.org - allowed us to examine Duckett's lineage, and we have presented our findings by creating a family tree for Duckett (see Figure 1) that can serve as a reference point as we unpack his complex history. Census records, tax lists, and marriage licenses helped us identify and track the correct Duckett family in Pennsylvania, and through numerous newspapers, we followed their social lives and careers, relocations, and legal proceedings. While this methodology reveals and contributes much new biographical information on Bill Duckett, many new questions emerged and opportunities for further research came to light with each important find.

Thomas Donaldson's depiction of Bill Duckett in Walt Whitman the Man (1896) emphasizes his role as Whitman's driver, helper, and friend, marking the first appearance of Duckett in Whitman biography $(105,193)$. Later biographies 


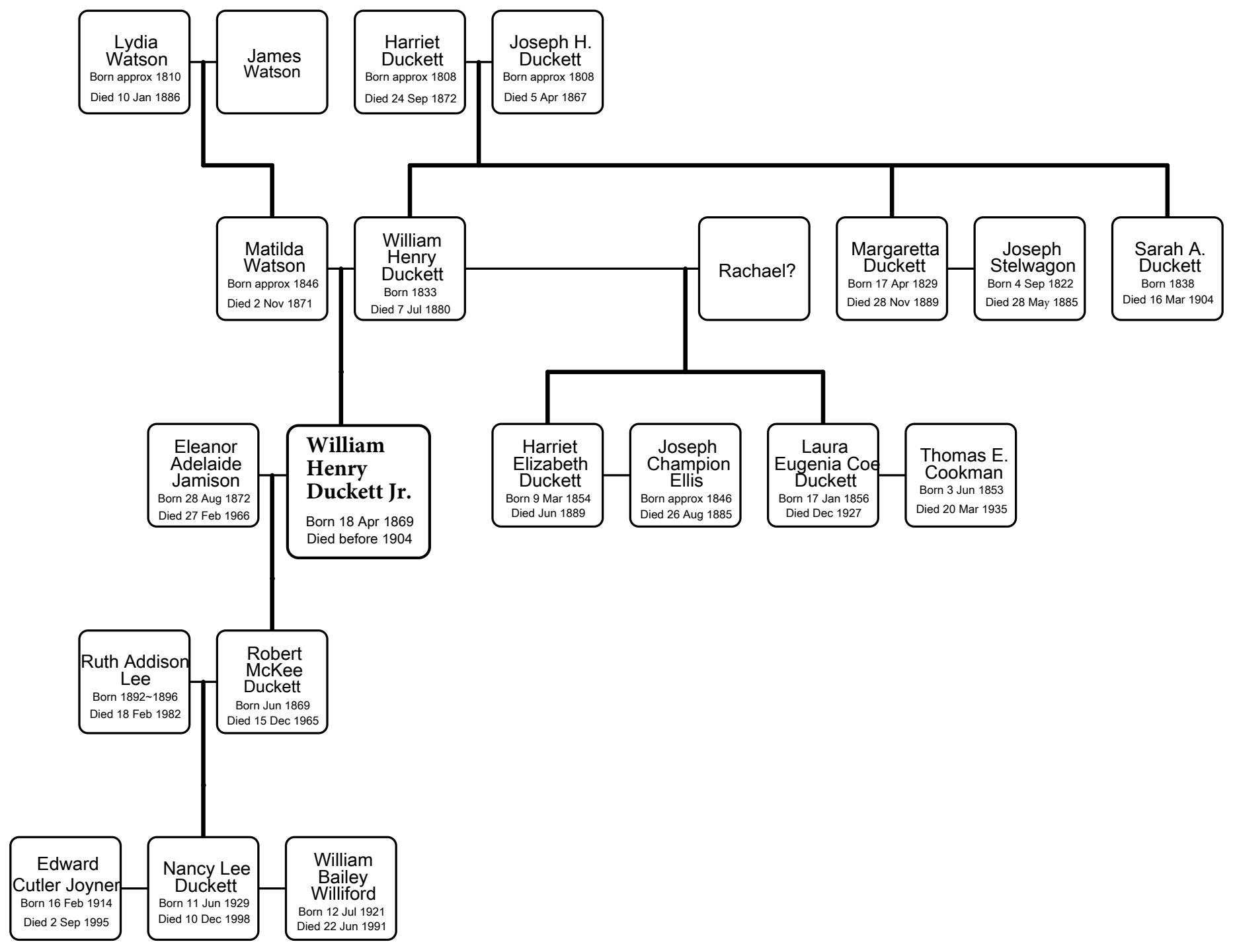

Figure 1: Family tree of William Henry "Bill” Duckett Jr. and his descendants. 
present Duckett as Whitman's “carriage driver and companion," offering perhaps a more nuanced view of their relationship, though providing limited insight into Duckett's own history. ${ }^{1}$ Duckett's life has received varying treatments in other historical and biographical works, ranging from complete omission (as in David Reynolds' Walt Whitman's America, Philip Callow's From Noon to Starry Night: A Life of Walt Whitman, Emory Holloway's Free and Lonesome Heart: The Secret of Walt Whitman) and passing mentions (Allen, Kaplan), to more extended portrayals (Folsom, Schmidgall's Walt Whitman: A Gay Life). Charley Shively's Calamus Lovers: Walt Whitman's Working-Class Camerados offers the most extensive consideration of a potential sexual relationship between Duckett and Whitman, based on Shively's reading of Whitman's sexuality and known attraction to younger and working-class men. If Duckett was a romantic partner for Whitman, they do not seem to have shared a long-term intimate relationship. This essay leaves the question of a romantic relationship between Whitman and Duckett open for further research since our focus will be on Duckett's life as he left both Camden and the poet behind and embarked on personal and professional journeys that took him to at least two other states. ${ }^{2}$

Nevertheless, photographically, Duckett's image remains inextricable from Whitman's, as two tintypes of the pair taken by Camden photographer Lorenzo Fisler are the only confirmed images of Duckett, each portraying him as Whitman's youthful assistant and companion, just as he is characterized by Whitman biographers. ${ }^{3}$ One photo, the first known image of Whitman taken outdoors, features the pair near a local meats and produce establishment in Camden, seated in Whitman's horse-drawn phaeton, a gift from his friends and admirers. The other, a studio portrait, presents Duckett as a round-faced youth, posed with his arm around the poet in front of a painted background depicting a view of the sea with a ship and a lighthouse (See Figures 2 and 3). Both photos are believed to date from 1886 when Whitman was nearly seventy, his characteristic flowing white beard dramatically contrasted by Duckett's fresh-faced and wide-eyed stare. Ed Folsom has suggested that the portrait, much like earlier images of Whitman and his longtime love interest Peter Doyle, resembles portraits of married couples from the period. ${ }^{4}$ At the time, Duckett would have been seventeen years old, fifty years the poet's junior, according to a Philadelphia city birth record citing his birthday as April 18, 1869. ${ }^{5}$

\section{Coming of Age in Philadelphia and Camden}

According to the 1880 Federal Census, Duckett lived with his grandmother, 
Lydia Watson, on Mickle Street in Camden, New Jersey, a few doors down from the house purchased by the aging poet in $1884 .{ }^{6}$ At some point, the new neighbors encountered one another, and they struck up a friendship. Whitman's conversations with Horace Traubel suggest that the relationship between Duckett and the poet took on a degree of co-dependence when the teenage boy moved into Whitman's home in 1886, likely around the time of the final illness and death of his grandmother. ${ }^{7} \mathrm{He}$ accompanied the poet on local and regional trips, their destinations ranging from the graves of Whitman's family to city hotels. On one occasion Duckett and the poet even enjoyed baked shad and champagne together at William Thompson's restaurant in Gloucester, New Jersey. ${ }^{8}$

Orphaned by the age of twelve, Duckett benefitted from Whitman's support, but Duckett's personal idiosyncrasies would lead a conflicted Whitman to pronounce him "bright - very bright" and alternatively a "young scamp." Tensions mounted at 328 Mickle Street soon after Duckett moved in; Whitman contended that he and his housekeeper, Mary Oakes Davis, never argued save over Duckett's presence in the home and his purported theft of items that went missing from Whitman's rooms. ${ }^{10}$ Disagreements ensued about whether Duckett was expected to pay room and board and the amount he owed, with arguments culminating in Davis filing suit in 1889 against Duckett to obtain the money she felt he owed for the time he lived there. Duckett claimed that Whitman had asked him to stay in his home free of charge; he believed he was the poet's guest when he agreed to the living arrangements. But Whitman, upon learning his name had been brought up at the trial, was equally adamant when he told Traubel that he had issued no such invitation. Whitman offered his own version of events: "By and by the boy's grandmother died: on her deathbed she pleaded with Mary to receive, trust, care for, the boy. . . . I left the matter with Mary entirely for her to do with as she thought best."11 Davis was successful in her suit, winning $\$ 190$, minus legal fees.

Davis may have felt justified in taking legal action against Duckett, since he had inherited a trust fund from which he may have drawn quarterly dividends and, therefore, should have been able to afford to pay for his board. "This young jackanapes has an income," Whitman told Traubel, "one of the big trusts in the city-the Fidelity" in Philadelphia. ${ }^{12}$ Despite this income, Duckett asked Whitman for money both before and after the 1889 trial. Not averse to helping a friend in need, Whitman gave Duckett $\$ 10$ in June of that year, during a visit in which Duckett confided his half-sister Harriet Duckett Ellis had died suddenly. He may have also shared plans to relocate, and Whitman was eager to keep in touch. "I am more interested than you know, Bill," Whitman told him, adding, "when you get settled in the city, write me how you like it, or come see me."13 
WWQR Vol. 39 Nos. $2 \& 3$ (FALl 202I/WINTER 2022)

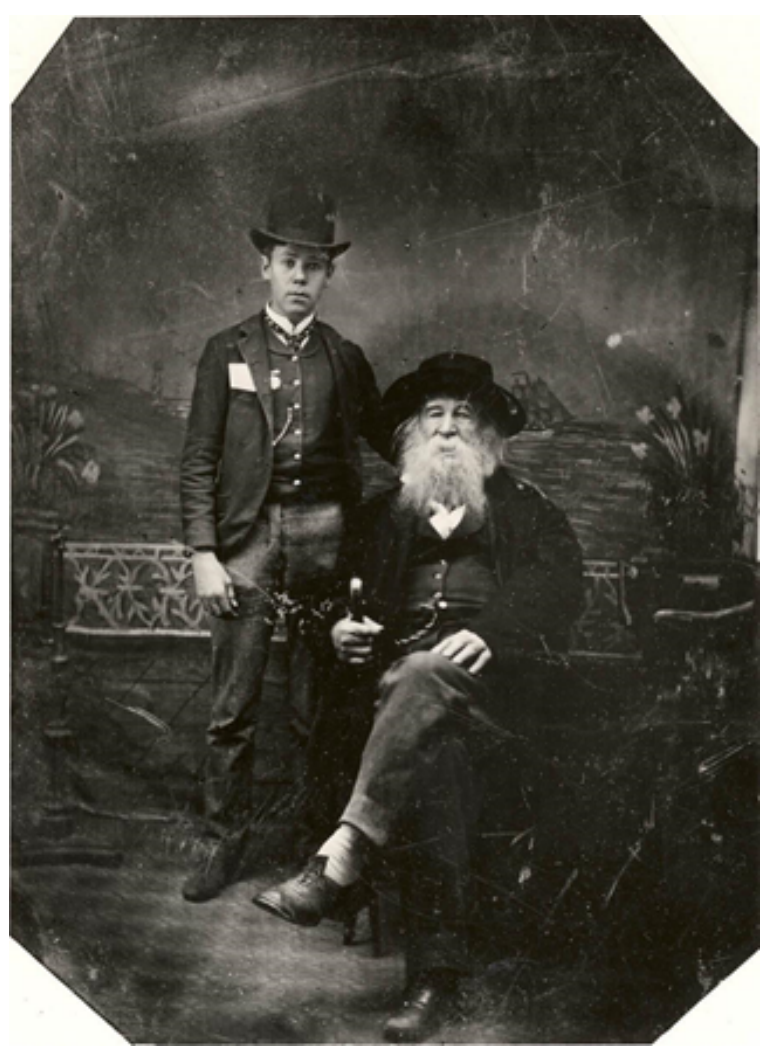

Figures 2 and 3: Walt Whitman and Bill Duckett, 1886. Ohio Wesleyan University, Bayley Collection.

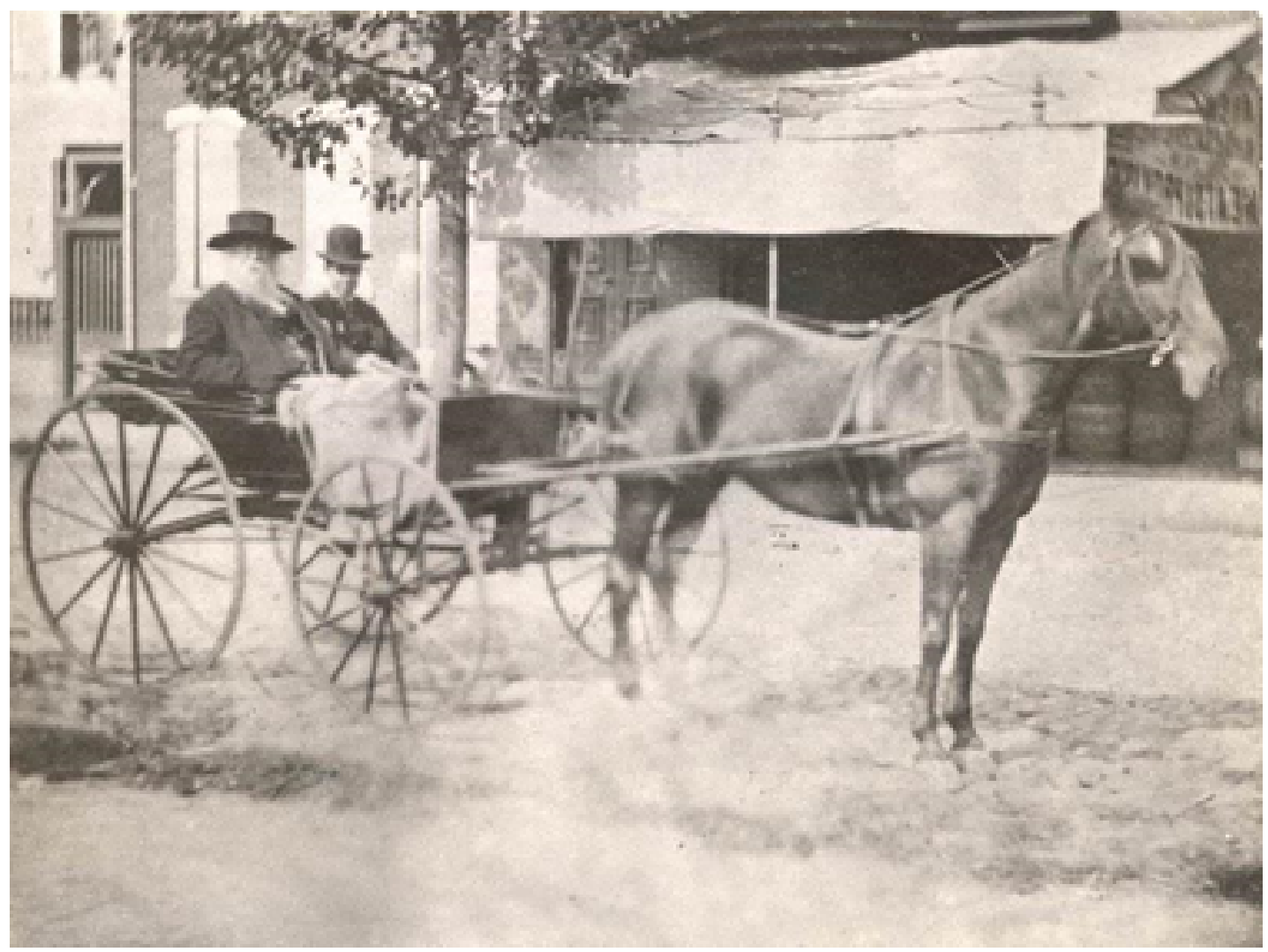


"The city" may refer to Philadelphia, from which Duckett would write a letter the following December, asking for more money. Admitting he had only $\$ 5$ to sustain him with rent due the next week, Duckett's letter claims Whitman would understand his situation, and indeed, the poet was likely privy to much knowledge about Duckett that may never be recovered. ${ }^{14}$ Whitman, by this time very ill, declined to send Duckett any cash, and this may be the last time he heard from the young man, as Duckett fell out of the Whitman circle and largely disappeared to history.

Whitman characterizes Duckett as taking "every advantage" of the poet and Mary's generosity, adding that Duckett paid them "probably fifty dollars in all: then stopped: not another cent," but Whitman claimed he took pity on the boy and let him stay anyway because "Bill would swear by all that was holy that he would by and by make all this right: would almost literally get down on his knees." Though this image seems overly theatrical, Bill's determination to compensate Walt and Mary might have been genuine, provided he had access to the trust fund of which Whitman seems to have been aware. A February 1889 notice of Davis's court award in the Philadelphia Inquirer confirms Whitman's assertion that Bill Duckett did have a trust through the Fidelity Company, a trust inherited through his father's family that was later the subject of numerous additional legal proceedings. The trust originated with Bill's grandfather, Joseph H. Duckett, a paper manufacturer in Philadelphia, ${ }^{15}$ who died in 1867 -two years before the birth of his grandson, Bill - and left behind a will that called for the division of his assets among his three children: Margaretta (Duckett) Stelwagon, Sarah A. Duckett, William Henry Duckett, Sr., and their heirs. ${ }^{16}$ The will, contested in a series of court proceedings that lasted at least until 1906, notes that William Sr. had already been married once; his first wife is not named in the proceedings and still remains unknown, but the suit does list their two daughters, Harriet Elizabeth (Duckett) Ellis and Laura E. C. (Duckett) Cookman. Harriet was born in 1854 and Laura approximately two years later, making them more than a decade older than their half-brother, Bill. ${ }^{17}$ Sometime after his enlistment in the Civil War in 1863, William Sr. either divorced or was left a widower, and by 1869 had married Matilda Watson, daughter of James and Lydia Watson of New Jersey, who was approximately twelve years younger. ${ }^{18}$ William and Matilda's only child, William Henry Jr., was born on April 18, 1869, and the family lived at 619 Montgomery Street in Philadelphia throughout Bill's infancy. ${ }^{19}$ According to the 1870 Federal Census, William Sr. was then working at a "roofing material store" and sharing his home with his wife Matilda, son William, and mother-in-law Lydia. ${ }^{20}$ But on November 2, 1871, when Bill was 
only three years old, his mother, twenty-five-year-old Matilda Duckett, died of consumption, leaving a will granting her mother Lydia and her young son a lifetime right to the home on Montgomery. ${ }^{21}$

Within two years of Matilda's death, William Sr. left the house at 619 Montgomery and moved back to his parents' home at $882 \mathrm{~N}$. $6^{\text {th }}$ Street in Philadelphia. ${ }^{22}$ For a short time, Lydia may have stayed on Montgomery caring for Bill, but the two did not remain in Philadelphia. By 1880, Federal Census records show they were boarding with Harry Sellars, a laborer, and his wife Hannah, at 334 Mickle Street in Camden, New Jersey, while William Sr. had moved in with his eldest daughter, Harriet, and her husband Joseph Champion Ellis in nearby Ellisburg. ${ }^{23}$ The Ellis family may have been helping to care for William Sr. in what would turn out to be the final year of his life, and when he died in 1880, Bill, now orphaned, was left in the sole care of his seventy-year-old grandmother. ${ }^{24}$ She and Bill seem to have remained in Camden in the years just prior to Whitman's arrival on Mickle Street. Contrary to some biographers of Whitman that claim Duckett's mother died in 1884, he was actually orphaned much earlier - well before he first encountered the poet - since Matilda died in 1871 and William Sr. nine years later in $1880 .^{25}$

From 1873, Whitman lived with his brother George in Camden, until the poet was able to purchase his own home at 328 Mickle Street in $1884 .^{26}$ At this time, Bill's grandmother Lydia is listed as living a few blocks away at 33 South 4th Street, though when Duckett signs Whitman's daybook around 1885, he continues to use the Sellars' address as his own (see Figure 4). ${ }^{27}$ When Bill met the poet for the first time, he was an active and athletic, if occasionally wayward, fifteen-year-old who appears to have been a cycling enthusiast, winning a prize in a one-mile bicycle race at Millville. ${ }^{28}$ The Cycle, a magazine for cyclists published in Boston, also credited Duckett with a second place finish in a half-mile race at the Merchantville Driving Park in May 1886, an event sponsored by the Camden Wheelmen. ${ }^{29}$ The following month Bill participated in the Camden Club boys' race of approximately half a mile and won first prize. ${ }^{30} \mathrm{He}$ may also have been the "Willie Duckett" who participated in a contest that involved skating blindfolded toward "a ham suspended from the ceiling by a string" at the Armory Rink in Camden. Bill managed to catch the ham, securing the prize in a contest against a "half-dozen fellows." 31 Whitman encouraged Bill's active pastimes, gifting the young man and his friends a brand new set of quoits, a ring-toss game popular among them, as Duckett's childhood friend John Browning later recalled for the Courier-Post. ${ }^{32}$ Browning even claims that the poet promised to use some of the proceeds from selling his writings to 
buy the neighborhood boys baseball suits after they proudly told him that they had decided on "The Walt Whitman Champion baseball club" for the name of their team. ${ }^{33}$ But, Browning admits, the boys never received their caps, shirts, and leggings, perhaps because Whitman may not have been able to afford to keep his promise.

Whitman was invested in Duckett's pastimes and friends, and also seems to have wanted to serve as a father figure for Duckett, whose only potential parental figures would have been his grandmother and extended family. John Browning vividly remembers Whitman stepping into the role of parent and disciplinarian once Bill moved into his home. According to Browning's account, when a rowdy and boisterous Duckett got into a fight with an African American boy of about the same age, Whitman seemingly grounded Bill as punishment, confining Duckett to his room for the evening. But Duckett's faithful band of neighborhood friends had other plans and concocted an elaborate plan to break out their comrade. Having stolen a ladder, they placed it against Whitman's house and began climbing up to Duckett's second-floor room, and they were well on their way to performing a daring rescue when the poet awakened and his "gray, bewhiskered face in a white night cap appeared at the window brandishing a large army pistol in each hand," thinking a band of robbers was attempting to enter his home. The "robbery story" grew in tall-tale proportions, with Bill and his friends disagreeing upon how many shots were fired, how badly the would-be rescuers were wounded, and the number of casualties in the incident. Regardless of what actually happened, the boys never again undertook such foolhardy missions to reclaim their companions when they were forbidden to come out and play. The band instead apologetically returned the stolen ladder to its rightful owner and went back to playing quoits and baseball in the evenings.

Bill might not have had as much time for his hobbies and neighborhood friends once he began driving for Whitman on outings in Camden and beyond, accompanying him to New York, Gloucester, Philadelphia, and Sea Isle City. ${ }^{34}$ An article in the Courier-Post described the poet's exploration of "Latham's Beach" with his Camden and Philadelphia friends, including Duckett, and highlighted "the good of the surf and shore, the sea air, the bathing" at Sea Isle City. ${ }^{35}$ Notably escorting Whitman to the 1887 New York Lincoln Lecture, Duckett "acted as valet and nurse, and it was on his arm the old man leaned as he came forward on the stage." ${ }^{36}$ At a reception following the lecture, Bill announced Whitman's guests, including a number of literary men: "In an hour Mr. Duckett had a very full hand of the cards of distinguished men and the crowd became so great that he gave up trying to announce each newcomer." 37 
According to Walt's recollection, "I paid him well for all he did for me," stating that his money was "as freely Bill's as my own." ${ }^{38}$ In just a few years Whitman's relation to Bill had evolved from one of neighbor and philanthropist to that of friend and employer.

Driving for Whitman was not Bill's only source of income in the 1880's, a decade in which he sought employment in a series of jobs. In March 1886, Whitman noted, for example, that "Billy Duckett" was in Camden and "working at [a] notion store" located at 257 Market Street. Whitman later wrote that the name of Duckett's employer was McKinley \& Horn, Notions \& Woolen Goods. ${ }^{39}$ It is possible that Duckett functioned as a clerk or salesman at the store through May. Beside the address for McKinley \& Horn, which Whitman pasted into his daybook, the poet wrote: "WHD left early June" (see Figure 5). William White explains his reading of this brief statement in a footnote, "By 'left' Whitman means that [Duckett] moved out of 328 Mickle Street" (DBN 384, n2133). In a later piece, White suggests that Duckett returned to Mickle Street in September but had left by $1888 .{ }^{40}$ Later biographers have offered various timelines for Duckett's boarding with Whitman, claiming that Bill lived with the poet for a period ranging from a few months to a few years. But if Bill had only been a full-time boarder on Mickle Street for one or two months, Mary's $\$ 190$ settlement would have grossly overcharged his trust fund. Given its placement on the daybook page beside the McKinley and Horne address, it seems more likely that Whitman's note about Bill's leaving indicates a change in employment for Bill instead of a decision to move out of the poet's home.

The theory of a shorter stay would be at odds with other evidence about how long Duckett lived with the poet. In a January 1889 letter to the Canadian physician Richard Maurice Bucke, Whitman describes Mary's suit as one that took place over "many months' board," and he proclaimed Duckett was guilty of having "fooled" her, making her wait for "eighteen months or more" for him to settle his debts. ${ }^{41}$ In a December 1886 letter, Duckett states, "I have been with [Whitman] for nearly a year," concluding with his signature and the poet's Mickle Street address. ${ }^{42}$ Using information likely collected in 1886 or 1887, the Howe's Camden City Directory (1887-1888) confirms Duckett as a resident of 328 Mickle Street. ${ }^{43}$ For the purposes of comparison, Whitman's daybook records him paying $\$ 16$ per month for his brother Eddy's board in 1886, and he paid $\$ 10$ monthly for his own lodging in $1884 .{ }^{44}$ If Bill was being charged a similar rate, Mary's suit would indicate he remained at Mickle Street for nearly a year, if not longer. This means that even if Duckett left the Notion store in June 1886, he likely continued to board at Mickle Street through the end of December and 
WWQR VOL. 39 Nos. 2 \& 3 (FALL 2O2I/WINTER 2022)

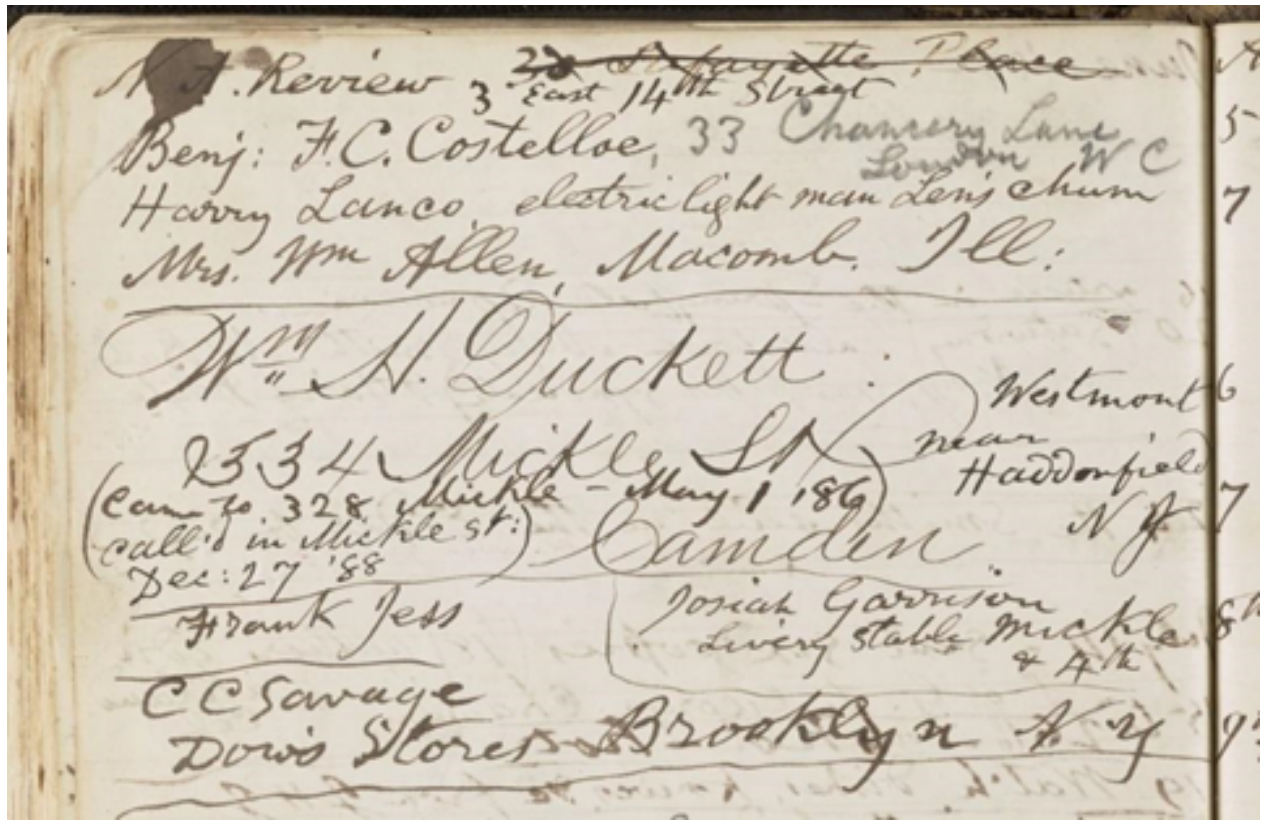

Figure 4: Duckett's

handwritten address from Whitman's Daybook, 1885. Feinberg Collection, Library of Congress.

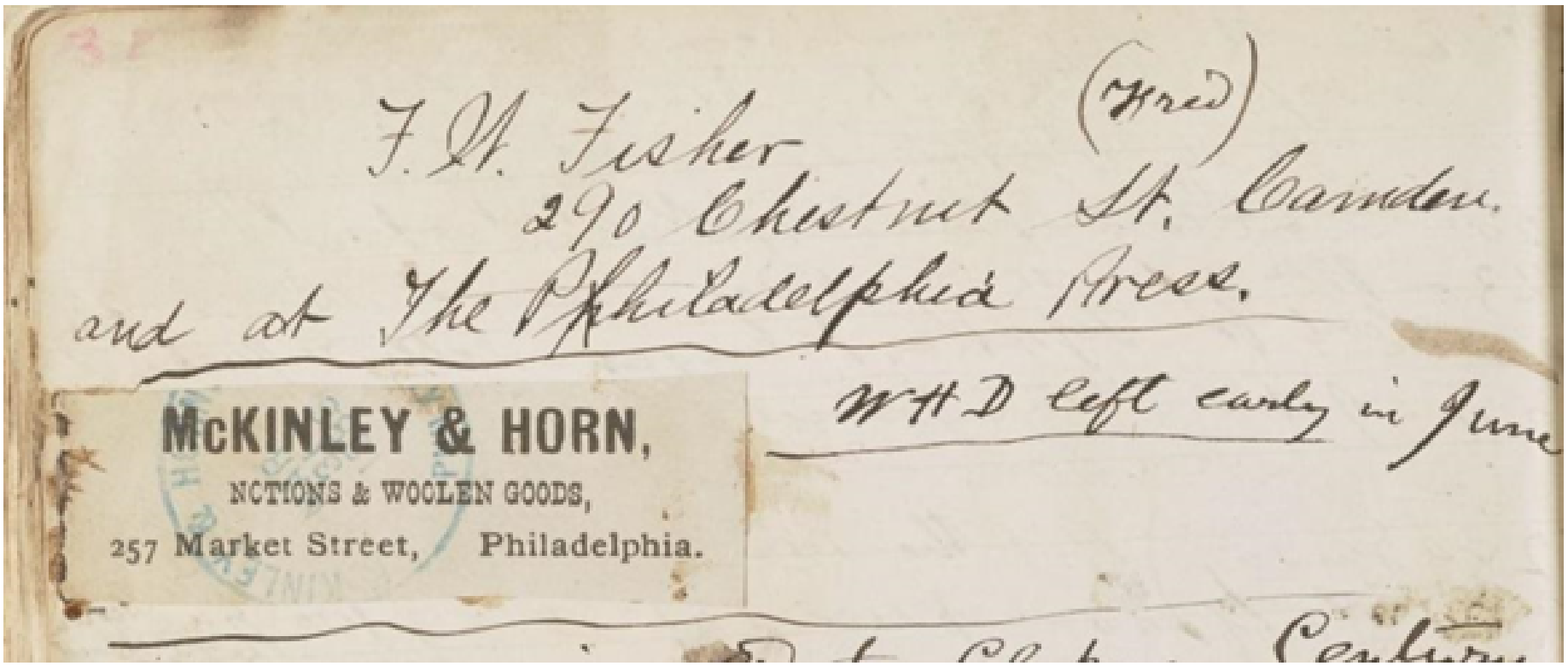

Figure 5: Whitman's Daybook, ca. 1886, showing note regarding Duckett's departure from the notions store. Feinberg Collection, Library of Congress. 
may have remained through the early months of 1887 . This revision to the timeline for Duckett's stay makes Mary's suit seem more reasonable with respect to the costs of room and board. By March 20, 1888, however, Duckett was settled in Haddonfield, and the Camden Telegram's "Pen Sketches of People we all See and Know," informed its readers that "W. H. Duckett of Haddonfield, spent Sunday in this city," indicating that although Bill had moved out of Whitman's home on Mickle Street, he was a familiar visitor to his old neighborhood. ${ }^{45}$

If Bill did quit his job at the notions store in June after approximately two months of employment, it would explain why Whitman wrote a letter of recommendation to the Philadelphia Press the same month, in hopes of finding the young man a new situation. Fred W. Fisher of the Philadelphia Press, whose address is included at the top of the daybook page just above that of McKinley and Horn, may have been the recipient of Whitman's letter inquiring about positions in the "counting room or on the writing staff" of the Press. ${ }^{46}$ In his letter, Whitman explains that Duckett is "used to the city, \& to life \& people," has "the first Knack of Literature," and vouches that Duckett is "reliable and honest." This literary "knack" implies that the educated young man may have been considering a career in the newspaper business. William White similarly observes that Duckett's letters appear to be written by "someone trained in a secretarial school," a far more likely scenario than that imagined by Charles M. Oliver, who describes Whitman's male friends, including Duckett, as "all laborers and barely literate." ${ }^{\prime 47}$ Not finding employment in the offices of the Philadelphia Press, Duckett took a job as a "news agent" "on the [railroad] train," from July to September 1886, when he was "laid off from RR after two months work," but "went on again soon," as Whitman recorded in his daybook. ${ }^{48}$ Seeking a new position for the eighteen-year-old Duckett by 1887, Whitman drafted another letter to a potential employer, this one written from the young man's perspective, that he signed "W H Duckett." Whitman presents Duckett to an unidentified correspondent "on the road" as "competent and determined to give satisfaction."

While Whitman may have intended to start Bill on the course of a career as a news agent or in newspaper work, Duckett's entry in Howe's Directory for 1887-1888 lists his profession as "telegraph operator." Whitman's notebooks record Duckett "practising" his skills at Sewell, proceeding to Stockton, serving as a "night operator" at the Railroad Station in Haddonfield, and later working in Ancora. The poet's timeline of Duckett's early career in telegraphy and railroad work shows him moving from station to station in 1887, perhaps in temporary positions before being laid off or transferred. ${ }^{49}$ The 1888-1889 Howe's Directory also includes Duckett in the Haddonfield section, returning to the city as a 
"telegrapher" at Haddon Station, as Whitman also noted..$^{50}$ Duckett's last known letter to the poet indicates he may have been employed with the Pennsylvania Railroad Company by December 1889, since the letter was written on pages with the company's name printed on them. These pages may be intended for recording telegraphic messages as each one includes pre-printed blanks for documenting the sender and recipient, as well as the "operator" that handled the message (see Figure 6). ${ }^{51}$

Duckett's final letter was sent in the same year other strains were put on the relationship between Duckett, Whitman, and those at 328 Mickle Street. Opening the year of 1889 was Davis's lawsuit against Duckett and her award payable from Duckett's trust. Roughly four months later in June, Duckett went to visit Whitman following the unexpected death of his half-sister Harriet, and the poet gave him $\$ 10$, the same amount he had given Peter Doyle when Doyle's mother passed away in $1885 .{ }^{52}$ Although Duckett made an effort to meet with Whitman again in November, he was not allowed upstairs to see the ailing poet. It is uncertain if Whitman's poor health or his household's distrust of Duckett's motivations prevented the visit, but Duckett's experience is similar to that of Peter Doyle, who did not visit Whitman as often as he would have liked because seeing the aging poet required "run[ning] the gauntlet of Mrs. Davis and a nurse and what not." "53 In his last letter to Whitman, Duckett writes, "I was over to see you some days since but you was unable to see me would like to see you very much." Duckett adds that Whitman would "understand the circumstances," perhaps alluding to either his current financial status or the tension between Duckett and "the people downstairs."

Frequent reprinting of a newspaper anecdote during the final months of the year may have also played a role in the termination of Whitman's and Duckett's friendship. Continued reappearances of the piece and/or its variants could have easily exacerbated a situation already pressured significantly by Duckett's financial difficulties and his requests for money from Whitman. In the article, published in the October 18, 1889, issue of the weekly Epoch, the author recalls, "Some time ago I was present at a literary tea given in Philadelphia to Walt Whitman. He at that time had a young boy some twelve years of age to drive him around." Following the article's publication, Traubel mentions having received several inquiries as to the young man's identity, to which Whitman responded, "Why - that must be Billy Duckett—who else?" and Traubel adds that the piece "amused [Whitman] into great laughter." ${ }^{4}$ The article states that Whitman was "proud of the boy and thought him an excellent reciter of poetry," a skill the boy demonstrated with a recitation of "O Captain! My Captain!" There are 
multiple retellings of the Epoch anecdote published in newspapers in at least ten states. The Chicago Inter Ocean publishes the account in its entirety but adds an original title presenting Duckett as "an American boy" and implying that he is a fitting companion and sidekick for America's poet. The Atchison Daily Champion [Kansas] labels Duckett "a true Yankee" and characterizes him as both Whitman's driver and caregiver.

The original Epoch account, after all, describes the youth's plans for a series of lectures on Whitman, and sarcastically attributes to him a "keenness of intelligence and a business sense" seldom found among youths. Duckett's lectures were to be based on the boy's original observations of his time with Whitman: "I keep a notebook, and I put down all he says into the notebook; and after he's dead I'm going to go round lecturing about him." This statement, outlining Duckett's supposed entrepreneurial intentions modelled after Whitman's own lecturing on the assassinated Lincoln, make his efforts sound like a precursor for Traubel's project and those of the other disciples who would ultimately preserve Whitman's legacy. Only these tongue-in-cheek references to Duckett's lecture plans from the Epoch piece are included in the shortened "personal" version that appeared in the December 1889 issue of Current Literature. Even Traubel took note of its publication, calling this version a "blundering passage," and Whitman adds that it "has most of all, lie in big, big type" but admits there is a grain of truth "underneath, in the smallest possible compass." However, Whitman never specified exactly which parts of the brief "personal" espoused falsehoods in big type and which details contained some truth.

Duckett did keep a series of personal notes written in pencil during his time with Whitman, some of which are currently held in the Feinberg Collection at the Library of Congress. They are accompanied by a coversheet in Whitman's hand, labelling them "Wm Duckett's Notes \&c: pencil draughts 1886-7." Duckett's daily recordings are no rival to Traubel's With Walt Whitman in Camden, however, and if there were notebooks or a more complete series of notes detailing Duckett's experience boarding with Whitman, they are currently lost or no longer survive.

The few pages that do remain date from November and December of 1886 and primarily account for meals, buggy rides, the weather, and guests at Mickle Street. Despite the Philadelphia Times report that "a boy" is "collecting the Poet's sayings," Duckett's notes include few direct quotes from Whitman. In a letter to Richard Maurice Bucke, Canadian physician and, later, literary executor to the poet, Duckett offers his notes for Bucke's collection of materials by and about Whitman, but as William White argues, since the notes contain 


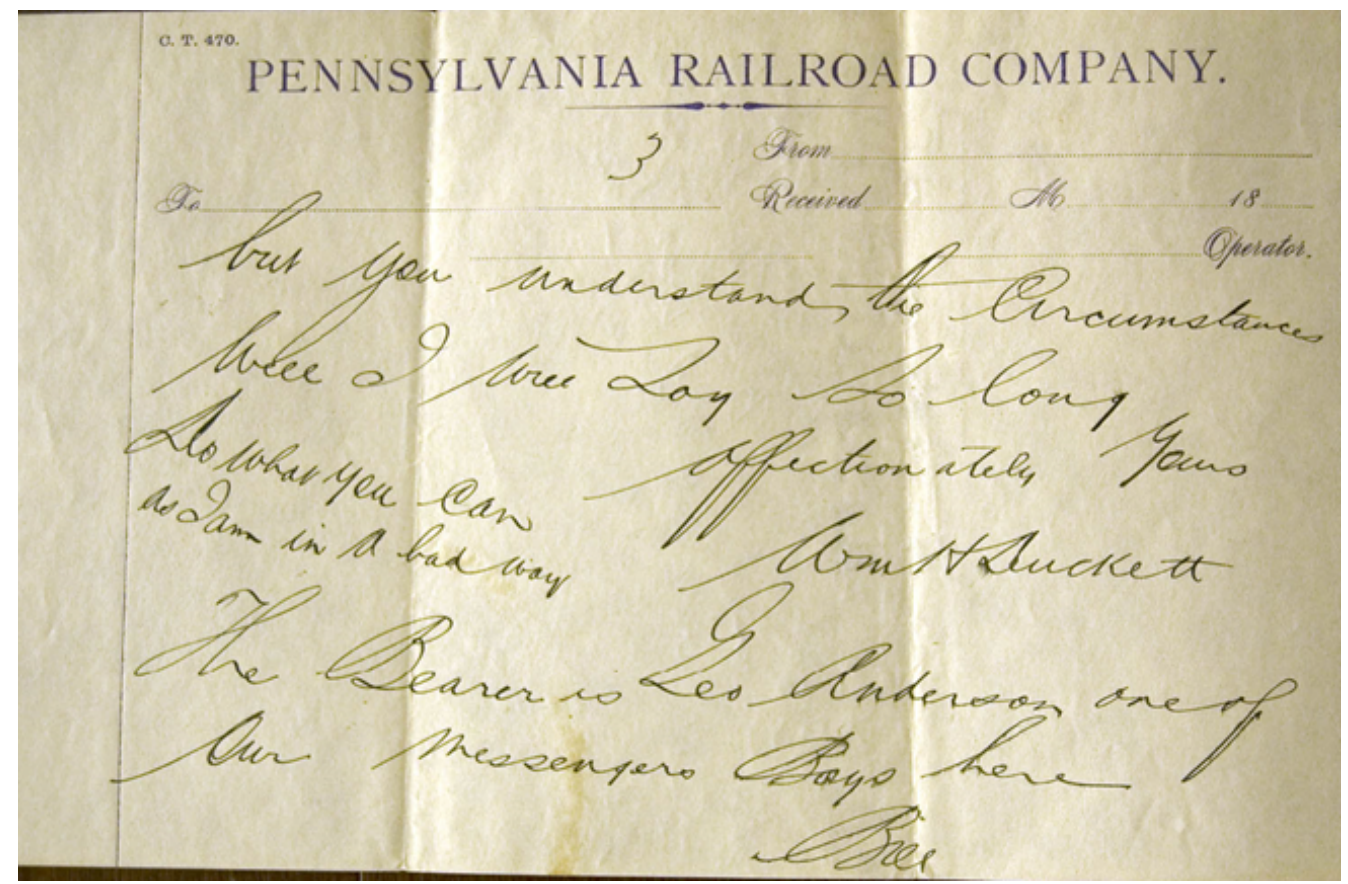

Figure 6: Letter from

Duckett to Walt

Whitman, December 20, 1889. Feinberg

Collection, Library of Congress.

Figure 7: Letter from

Duckett to R. M. Bucke.

Feinberg Collection,

Library of Congress.

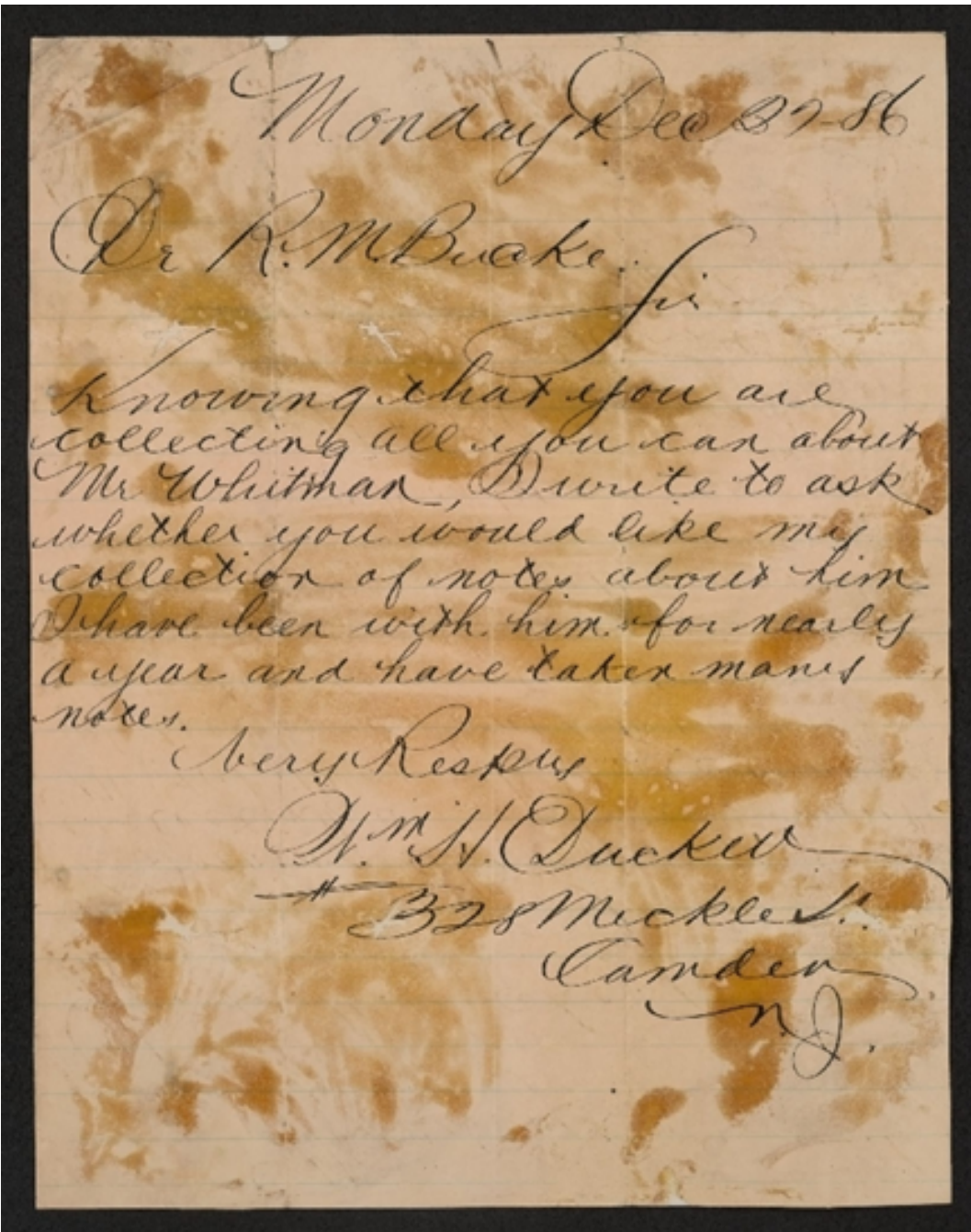


little valuable information, it is unlikely Bucke would have found them worth acquiring (see Figure 7). Despite the possibility presented by F. DeWolfe Miller that Whitman may have collaborated in the writing of the notes-perhaps intending them as a source of income for Duckett-Bucke pronounced Duckett a "moral imbecile," and he likely felt no obligation to help Bill financially by purchasing them. ${ }^{55}$

Dating from roughly the same period as Duckett's notes, Whitman composed a glowing narrative of his friendship with Duckett, written from Duckett's perspective, like Whitman's previous letter to one of Duckett's potential employers. Miller describes this narrative as Whitman's "unique attempt to present himself as seen by a youth," but adds that "every sentence except the last has its precedent in previous writings about himself." 56 The mentions of Whitman's health complaints alongside contradictory descriptions of his "good appetite" and "full-blooded" body are typical of his self-promotion, and the narrative even includes a passing endorsement for Specimen Days. But the narrative's physical descriptions of Whitman as, "close to six feet high" and "weigh[ing] over 200 pounds" are far more detailed than any of Duckett's notes, which barely mention Whitman's appearance. While Whitman attributes this degree of physiological attention to a youthful perspective, Duckett's notes contain more description of the poet's horse than of the poet himself and seem to be little more than the dailies of Whitman's carriage driver. Perhaps intending for the notes to provide both another small source of income for the young man, as well as a defense of Whitman's character and even their own relationship, Whitman's ghostwritten narrative emphasizes the poet's "great frankness and naturalness," and pronounces him "entirely free from indelicacy or any unchastity." ${ }^{57}$ It also serves to enumerate the qualities Whitman wanted youth to see in him, perhaps as a model for emulation, including "patience, good nature, and a sunny disposition." Among these virtues are Whitman's selfless giving "to the poor" and his willingness to assist "indigent old persons and widows constantly, sometimes with food or fuel or money, sometimes paying the rent." This last act of charity sounds especially ironic in light of the 1889 suit against Duckett. Whitman's final gift of $\$ 10$ to Duckett, though, shows that there may be some sincerity to the narrative's conclusion that "he [Whitman] always gave me good advice and help and was the best friend I ever had." This final sentence also sounds eulogistic and may lend some credibility to the Epoch's account of the boy who will lecture on Whitman "when he is dead."

The year 1889, with the lawsuit and the press coverage of the DuckettWhitman bond, culminated in what appears to have been a complete severance 
of the friendship, and Whitman had no known connection to Duckett during the last two years of his life. After the year's end, the specifics of Bill Duckett's life have been hazy at best, save the possibility that he posed nude for the painter and photographer Thomas Eakins at the Philadelphia Art League. ${ }^{58}$ While there are still many gaps in Duckett's biography, the developing narrative of his life in the 1890s is equally, if not more, interesting than that of his youth. As far as we know, he was unattached at this time and was starting to make his own way in the world; once he had the skills of telegraphy, he could apply for positions that allowed him to explore a number of cities. His frequent moves might help explain why the adult Duckett has proven hard to trace, since telegraphy may have taken him as far west as Ohio and, later, as far south as North Carolina. A William H. Duckett, Telegraph Operator for Western Union, appears in the 1893 Cincinnati, Ohio City Directory. ${ }^{59}$ Not referenced in any previous or subsequent directories for the city, this William Duckett lived in a boarding house on W. 4th Street, and he only remained there for one year. Employment with Western Union may have led Bill to move from Cincinnati to the city of Charlotte, North Carolina, by April of 1895.

\section{Bill at Home in the South}

The April 12, 1895, issue of the Daily Concord Standard notes that "Mr. Wm. H Duckett" had temporarily left Charlotte to work as a "night operator" in the neighboring city of Concord. ${ }^{60}$ Back in Charlotte shortly afterward, ${ }^{61}$ Duckett was living at 308 South Church Street, a popular boarding house owned by a Mrs. Bradshaw. ${ }^{62}$ Early records of Tryon Street Methodist Episcopal Church list Duckett as a member residing at the Church Street address, also home to fellow church members, the Creswell family. ${ }^{63}$ Sharing the boarding house were Ed F. Creswell, his wife Mamie (Frazier) Cresswell, Mary I (Jamison) Creswell, and her daughter Annie. While living on Church Street, Duckett helped his friend Charles Frazier secretly elope with Annie Cresswell despite her mother's objections to their union. ${ }^{64}$ Serving as official witness to the marriage, Duckett signed the marriage certificate and listed the city in which he was born as "Philada," an abbreviation for Philadelphia he had used previously on an extant letter to Whitman (see Figure 8 for handwriting comparison). ${ }^{65}$ The Frazier-Cresswell wedding foreshadows Duckett's future in Charlotte, since by July of that year, he would apply for a marriage license of his own.

At some point, after arriving in North Carolina, Bill Duckett began a relationship with Eleanor Adelaide "Addie" Jamison, the daughter of Robert 
McKee Jamison and his second wife Sarah L. (Todd). Addie was dubbed by the local press as "one of the fairest of Charlotte's fair ones and otherwise attractive." 66 Though possibly Bill was drawn to Addie's charm, the Jamisons' social position would also have appealed to him; Mr. Jamison had at one time been a prominent blacksmith, and the Jamisons were a well-connected family. ${ }^{67} \mathrm{On}$ July 2, 1895, Duckett, then age twenty-six, and Addie, twenty-two, applied for their marriage license, and a private ceremony in nearby Paw Creek followed two days later. ${ }^{68}$ This certificate significantly notes the connections that allow us to identify William H. Duckett of Charlotte as Whitman's Bill. ${ }^{69}$ With Philadelphia listed as his city of birth and his deceased parents recorded as William H. and Matilda Duckett, also of Philadelphia, the information is too consistent with what we know of Bill Duckett's history to refer to any other Bill Duckett from Pennsylvania. The Duckett-Jamison wedding announcement that later appeared in the paper notes that, although Duckett had not been in North Carolina very long, he had made many friends in Charlotte. ${ }^{70}$ The paper added that Duckett, a telegrapher by trade, was planning to connect with the city's YMCA, an affiliation he could have established through the local church. By all accounts, the Ducketts settled into their new life as a wedded couple, renting a home with Addie's mother, the recently-widowed Sarah, shortly after the marriage. Sarah Jamison died less than a year later, in May 1896, about a month before the birth of Bill and Addie's first and only child, a son named Robert McKee after Addie's father. ${ }^{71}$

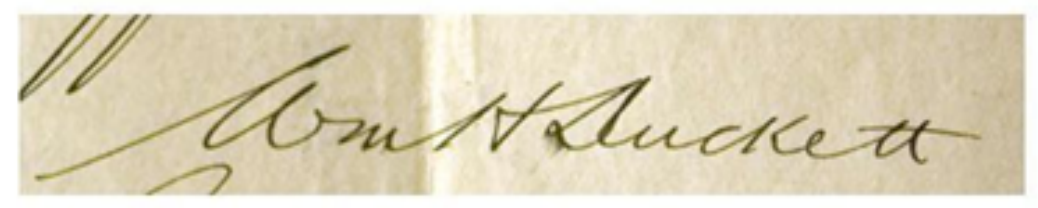

Letter from Wm. H. Duckett to Whitman in December 1889

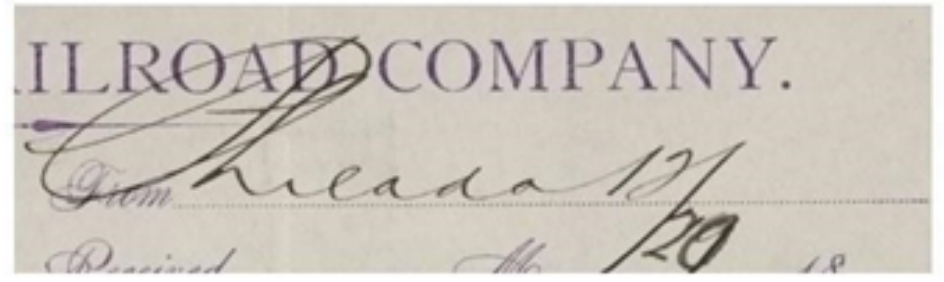

From letter to WW in December 1889

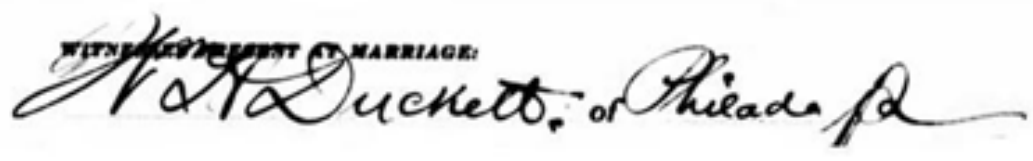

Witness to Charles Frazier and Annie Creswell's Marriage, June 1895
Figure 8: Handwriting comparison of letter from Duckett to Whitman (above) and as witness to the Fraizer-Creswell marriage (below). 
"At midnight tonight the year 1896 will pass into history," declared a writer for the Mecklenburg Times in a report on Tryon Street Methodist Church's New Year's Eve service: "This year has been an eventful one for Charlotte, the State, and the country at large." 72 The year was no less eventful for the Ducketts and Jamisons; the birth of Robert, a change of address, and the death of Addie's mother mark 1896 as a year of rapid change. The Christmas season offered no respite from transition and leave-taking. At some point around Christmas Eve, when baby Robert was nearly seven months old, as the divorce records would later indicate, Bill Duckett suddenly abandoned his young family and left Mecklenburg County and possibly even the state of North Carolina. ${ }^{73}$ What happened during the holiday season that made Bill leave so abruptly is uncertain, and many questions remain unanswered: Were there past mistakes he was worried would be found out? Had he given up attempting to fit into the comfortable society the Jamison family represented? Had he conned his new family out of assets and fled town, living up to his notorious reputation among Whitman's friends? It is even possible to imagine the couple simply parting ways, with Duckett returning to his transitory lifestyle and Addie remaining in the social circles to which she was accustomed, but the official records offer no definitive explanation for Duckett's abrupt departure.

After abandoning his wife and small child in December 1896, Duckett's whereabouts recede back into obscurity. An index card at the National Archives provides scanty information on a William H. Duckett who enlisted in Company E of the Second North Carolina Infantry during the Spanish American War of $1898 .{ }^{74}$ The volunteer roster lists this Duckett as coming from Charlotte and enlisting for two-years on June $13^{\text {th }}$, only to be mustered out of service on November $23^{\text {rd }}$ of the same year, a few months after the end of the war. This company did not see any action, but spent the duration of 1898 training in Georgia, before the men were mustered out near Tarboro, North Carolina. ${ }^{75}$ Until more conclusive evidence is found on this Private William H. Duckett, it is impossible to determine whether this proves Addie's ex-husband abandoned her and later pursued a brief military service, though the notion is enticing.

For four years after Bill's departure, Addie raised their son and continued to participate in social events around Charlotte. In the 1900 census, mother and son are listed alongside the head-of-household William Duckett Jr, a telegraph operator by profession, ${ }^{76}$ who was perhaps included as a mere formality, since the divorce records indicate no one had seen or heard from him during the previous four years. ${ }^{77}$ Living with Addie at 3001/2 South Church Street was her brother Dr. Isaac Wilton Jamison, who would serve as young Robert's male 
authority-figure in his father's absence. On December 6, 1900, Addie filed for divorce in Mecklenburg County Court, which she was granted in March of the following year along with sole custody of her four-year-old son. ${ }^{78}$ Nine months after the divorce was finalized, on the day after Christmas, Addie celebrated her second marriage. In a well-attended ceremony, she exchanged vows with Warren Stokes Shelor in her parlor on Church Street which was "beautifully decorated with holly and mistletoe," according to the Charlotte Observer. ${ }^{79}$

The Shelor-Duckett wedding garnered much more fanfare than that of Duckett-Jamison. Surrounded by well-wishing friends and given away by her brother, Addie wore "a lovely gray poplin dress, trimmed in crepe de chine lace." Shelor was a clothing salesman originally from South Carolina who would later become a haberdasher in Charlotte. ${ }^{80}$ In 1903, the couple welcomed their only child together, Warren S. Shelor, Jr. The well-connected family was frequently featured in local papers; the Charlotte Observer, for example, printed a picture of Warren, Jr. under the heading of "Belles and Beaux of the Future" in October $1904,{ }^{81}$ and letters to Santa from Robert and his half-brother indicate that the two were brotherly affectionate, at least when young. ${ }^{82}$

\section{Bill Duckett's Death and Legacy}

In 1904, eight years after Duckett's quick departure from Charlotte and the year his son Robert turned eight, the Pennsylvania courts audited the Joseph $\mathrm{H}$. Duckett estate. It is uncertain whether court officials contacted Addie or the Shelor family had previously connected with Bill's relatives in Philadelphia, but a notice published in the Philadelphia Inquirer announced that the case would be discussed in early June. ${ }^{83}$ That same month in Mecklenburg County, Dr. Isaac Wilton Jamison filed to be the guardian and financial manager for Robert Duckett until he came of age. The guardianship documents indicate that Robert stood to inherit up to $\$ 4,500$ from a Fidelity Trust that had belonged to his father, Bill. ${ }^{84}$ Jamison then went to Philadelphia, "to look after some property interests inherited by his little nephew." 85 It cannot be a coincidence that Jamison went to Philadelphia regarding an inheritance for Robert the very week that the trust was due to be audited and distributed. This evidence decisively reaffirms that Robert McKee Duckett was the child of Bill Duckett, something previously unknown to Whitman scholars.

But the court dealings with the estate of Joseph H. Duckett were still not entirely settled; it would not be until 1906, thirty-nine years after Joseph's death, that the heirs would see the distribution of the remaining assets. Joseph's eldest daughter Margaretta and her husband, Joseph Stelwagon, concerned about their 
children's share of the inheritance, appealed the court's earlier ruling regarding the division of the estate. ${ }^{86}$ The previous verdict was reversed, and the descendants of Joseph Duckett's children, including Robert McKee Duckett, became legal heirs entitled to a portion of the estate. Without the documentation of these legal battles over the inheritance that clearly list Robert as the surviving son of Bill and Whitman's casual reference to Duckett's trust fund, we might never have found Bill in North Carolina.

What can be ascertained by the transfer of guardianship of Bill Duckett's son to I. W. Jamison and Robert's claim to the inheritance of the trust fund is that the Pennsylvania courts and the Fidelity Company knew or at least presumed Bill Duckett to be deceased by the time of the 1904 court proceedings. One possible narrative of Bill's demise ends in a Philadelphia jail cell on September 21, 1902, when, according to a newspaper notice the following morning, "William H. Duckett, 35 years old, was found dead in a cell at the Eleventh and Winter streets station house." ${ }^{87}$ The two-paragraph notice details how Duckett had been arrested and taken to Hahnemann Hospital where "physicians diagnosed his case to be acute alcoholism." The man was taken back to the station house and died at some point in the evening; his body was discovered by the morning staff the next day. If this is truly Whitman's Bill, however, it would be the first record of Duckett's struggle with alcoholism, and the absence of such references in Whitman's letters and notebooks concerning the young man introduces questions to this claim for his identity.

News of this man's death appears twice in print, with the initial write-up being followed by a brief notice of funeral details two days later. In both cases, he is named "William H. Duckett," a name at odds with both the interment record and death certificate that clearly give the name "William A. Duckett." 88 The changing middle initial could have several origins, and it is easy to imagine "H" being verbally slurred into "A," mistakenly transcribed in a station ledger, and subsequently corrected for the newspaper by a relative or friend of Duckett. Initially interred at Oddfellows Cemetery on September 24, 1902, Duckett's body would not rest undisturbed for long, as he continued in death the constant relocations he had made in life. This William was moved to Lawnview Cemetery when the city of Philadelphia purchased Oddfellows Cemetery in 1950 and disinterred the bodies as part of an early stage of urban renewal. While Bill Duckett's fate-exactly when and how he died-remains uncertain, this "William A. Duckett," nevertheless, remains a strong candidate for Whitman's Bill (William H.).

It is unfortunate that Bill Duckett died before he had a chance to recon- 
nect with his son or even to learn from newspaper accounts about Robert's military service and later, his career and family in Raleigh, North Carolina. In 1917, twenty-one-year-old Robert left Raleigh for military training at Camp Sevier following the United States' entry into World War I. A notice in the Philadelphia Inquirer indicates that a Fidelity Trust account in the name of Robert M. Duckett's guardian, presumably still Isaac Wilton Jamison, was audited yet again..$^{89}$ Soon to be a legal adult, Robert may have gained full control of his Trust as he prepared to leave his reporting job and enlist in the First World War. The Charlotte News announced that he resigned from the local staff of the Raleigh Times to serve in the Army's $60^{\text {th }}$ infantry brigade..$^{90}$ " $[\mathrm{It}]$ nearly killed me when I saw him marching away in his uniform," Addie confides in a letter to her brother shortly after Robert's departure. For her, that day was "like a funeral," yet she took comfort and pride in being "the mother of such a son" who fought "for the women and children, not only of this country, but those across the sea." ${ }^{\prime 11}$ In a letter written from France on the date of the Allied offensive (July 15, 1918) and published in the Raleigh News and Observer, Duckett declares that "people at home" are "ignorant as to the real game of war as it is played nowadays." ${ }^{2} \mathrm{He}$ adds, "an opinion may be had from the press and periodicals, but the 'real thing' is a picture that cannot be painted," a sentiment that poignantly echoes Whitman's own claim that the "real" Civil War would "never get in the books." 93

Within a decade after returning from the War, Robert Duckett married Ruth Addison Lee (1926), ${ }^{94}$ was treated for rabies (1929), ${ }^{95}$ and celebrated the birth of his daughter, Nancy (1929), in the same year that also saw the Great Stock Market Crash. ${ }^{96}$ From 1935-1938, in the middle of the Great Depression, he worked for the Unemployment Service in Raleigh as senior interviewer and later as district manager. ${ }^{97} \mathrm{He}$ would go on to reestablish his pre-World War I affiliation with North Carolina newspapers, and at the time of his passing on December 16, 1965, he had been librarian for the Raleigh Times and the Raleigh News and Observer for ten years. ${ }^{98}$ He was survived by his wife, daughter, and mother; Addie died the following year, at the age of $94 .{ }^{99}$ Addie, Robert, and several other members of The Duckett/Shelor family are buried in Oakwood Cemetery in Raleigh. Robert's daughter Nancy followed in her father's footsteps and worked as a journalist and public information officer of the Department of Community Colleges of the State Board of Education; her articles were published in numerous North Carolina newspapers. Although she was married twice, as far as we know, she died childless in 1998, the last known descendant of Bill Duckett. ${ }^{100}$ 


\section{Conclusion}

During the years Bill Duckett knew America's poet, he served as Whitman's driver, attendant, hired help, and would-be chronicler; but his potential to fulfill a more central role was unrealized as the poet neared the end of his life. Despite having the drafted reminiscence in Whitman's hand and a short series of personal recordings that reflect daily life on Mickle Street, Duckett seems never to have published that material, perhaps not wanting to draw attention to the Davis lawsuit against him for failing to pay room and board. Nor was Duckett to become the biographer of Whitman's last years: that place would belong to Horace Traubel, who spent years documenting his conversations with Whitman with his voluminous With Walt Whitman in Camden. Warren Fritzinger, the son of a sea captain and a ward of Davis, displaced Duckett as Whitman's young companion and served as his final nurse. ${ }^{101}$ Although Duckett might not have wanted to be found after he abandoned his family in December 1896, the record of this elusive Whitman comrade is beginning to come into focus. The years following his service to Whitman are no longer entirely a mystery; Duckett's work as a telegraph operator and attempt at building a family in North Carolina give us insight into the adult life of one who forever remained a teenager in the eyes of Whitman chroniclers. Duckett's movements as a telegrapher travelling from city to city merit further research, as do his whereabouts following his hasty departure from North Carolina. Often considered a con man and "moral imbecile" in Whitman's inner circle, there might remain more skeletons in Duckett's closet to be revealed, and, if he was the con man they accused him of being, many that might never be known.

While discussing Mary's suit against Bill Duckett with Traubel, Whitman states his conviction that "there seem to be some men, some natures, that must develop, must display, the bad, just as the snake gives its poison, just as the tiger exercises its ferocity." 102 Whitman's emphasis on latent character flaws may indicate that Duckett's faults had become increasingly visible to the poet over time. Yet, Whitman continues to seem conflicted in his estimate of Duckett: "poor boy! poor boy! I pity him: I would receive him today if he needed me: would help him: I am sure I would be the first to help him," a sentiment that suggests Whitman may have truly aspired to be the "best friend" Duckett ever had. Even as Duckett grew up and sought employment that would take him farther and farther away from Camden, Whitman likely remained "more interested" in Bill's life and advancing career than Duckett would ever know, even though the two were no longer able to keep in touch across time and distance. Our research has revealed previously unknown details and offers a much fuller picture of 
Duckett's development into manhood, his career and his family, a future that Whitman never witnessed. Never able to take root in one locale, his was a lifetime of relocation, forever caught between staying and going, bachelorhood and marriage, North and South, as new responsibilities attempted to pin him down.

\section{The University of Iowa}

\section{Notes}

1 See Ed Folsom and Kenneth M. Price, Re-Scripting Walt Whitman: An Introduction to His Life and Work (Malden, MA: Blackwell, 2005), 122; Gay Wilson Allen, The Solitary Singer: A Critical Biography of Walt Whitman (New York: MacMillan, 1955), 523; Justin Kaplan, Walt Whitman: $A$ Life (New York: Simon and Schuster, 1980), 28; Jerome Loving, Walt Whitman: The Song of Himself (Berkeley: University of California Press, 1999), 437.

2 Thomas Donaldson, Walt Whitman the Man (New York: Francis P. Harper, 1896); David S. Reynolds, Walt Whitman's America: A Cultural Biography (New York: Vintage Books, 1996); Philip Callow, From Noon to Starry Night: A Life of Walt Whitman (Chicago: Ivan R. Dee, 1992); Emory Holloway, Free and Lonesome Heart: The Secret of Walt Whitman (New York: Vantage Press, 1960); Gary Schmidgall, Walt Whitman: A Gay Life (New York: William Abrahams; Dutton, 1997); Charley Shively, Calamus Lovers: Walt Whitman's Working-Class Camerados (San Francisco: Gay Sunshine Press, 1987.

3 Photograph of Walt Whitman and Bill Duckett, 1886, by Lorenzo Fisler. Ohio Wesleyan University, Bayley Collection, Available on the Walt Whitman Archive (www.whitmanarchive.org) ID: owu.00068. Hereafter, $W W A$; Photograph of Walt Whitman and Bill Duckett in Phaeton, Camden, NJ, 1886, by Lorenzo Fisler. Ohio Wesleyan University, Bayley Collection, WWA ID: owu.00068. The photograph of Whitman and Duckett in his phaeton was also published in Thomas Donaldson's Walt Whitman The Man, between pages 192 and 193.

4 Ed Folsom, "Whitman's Calamus Photographs," in Breaking Bounds: Whitman and American Cultural Studies, ed. Betsy Erkkila and Jay Grossman (New York: Oxford University Press, 1996), 193-219.

5 “Pennsylvania, Philadelphia City Births, 1860-1906," database with images, FamilySearch; image 227 of 628; City of Philadelphia, Department of Records, Pennsylvania.

6 Year: 1880; Census Place: Camden, Camden, New Fersey; Roll: 773; Page: 141D; Enumeration District: 044. Ancestry.com and The Church of Jesus Christ of Latter-day Saints. 1880 United States Federal Census. Lehi, UT: Ancestry.com Operations Inc, 2010. Records of the Bureau of the Census, Record Group 29. National Archives, Washington, D.C.

7 Death records for Lydia Watson, Bill's grandmother, record conflicting dates for her death. Ancestry.com records January 10, 1886, citing the New fersey, Deaths and Burials Index, 1798-1971, while Familysearch.com, citing the same source, gives January 10, 1887.

8 Daybooks and Notebooks: Daybooks, December 1881-1891, ed. William White (New York: New York University Press, 2007), 2:421. Hereafter, DBN. 
9 Horace Traubel, With Walt Whitman in Camden, 9 vols. (various publishers, 1905-1996), 4:65. Hereafter, WWC. Available on the Walt Whitman Archive.

$10 W W C, 5: 82$.

$11 W W C, 4: 65$.

$12 W W C, 4: 65$.

$13 W W C$, 5:329-330. Harriet Duckett Ellis (1853-1889), wife of Joseph Champion Ellis, was the eldest daughter of William Henry Duckett Sr. and his first wife, whose name is currently unknown.

14 Letter from William H. Duckett to Walt Whitman, December 20, 1889. WWA ID: loc.02004. Charles E. Feinberg Collection, Library of Congress. Duckett leaves off the year in his dating of the letter, but tells Whitman, "I was over to see you some days since but you was unable to see me." He is possibly referring to a visit made in November 1889. Traubel relates Whitman saying on November 29 th, "Billy was here to see me the other day, but they would not let him in - the people downstairs" (WWC, 6:167).

15 "Death of an Old and Respected Citizen," The Philadelphia Inquirer (April 8, 1867), 2.

16 Pennsylvania State Reports, vol. 214. William I. Schaffer, reporter (The Banks Law Publishing Company, 1906), 362-368.

17 Birth record for Harriet: Historical Society of Pennsylvania; Philadelphia, Pennsylvania; Historic Pennsylvania Church and Town Records; Ancestry.com. Pennsylvania and New Jersey, Church and Town Records, 1669-2013 [database on-line]. Lehi, UT: Ancestry.com Operations, Inc., 2011; Birth record for Laura: Source Citation Historical Society of Pennsylvania; Philadelphia, Pennsylvania; Collection Name: Historic Pennsylvania Church and Town Records Source Information Ancestry. com. Pennsylvania and New Jersey, Church and Town Records, 1669-1999 [database on-line]. Lehi, UT: Ancestry.com Operations, Inc., 2011. Original data: Historic Pennsylvania Church and Town Records. Philadelphia, Pennsylvania: Historical Society of Pennsylvania. Methodist Church Records. Valley Forge, Pennsylvania: Eastern Pennsylvania United Methodist Church Commission on Archives and History 2 42154_329967-00044.

18 War Record: National Archives and Records Administration (NARA); Washington, D.C.; Consolidated Lists of Civil War Draft Registration Records (Provost Marshal General's Bureau; Consolidated Enrollment Lists, 1863-1865); Record Group: 110, Records of the Provost Marshal General's Bureau (Civil War); Collection Name: Consolidated Enrollment Lists, 1863-1865 (Civil War Union Draft Records); NAI: 4213514; Archive Volume Number: 1 of 1 Source Information Ancestry.com. U.S., Civil War Draft Registrations Records, 1863-1865 [database on-line]. Provo, UT: Ancestry.com Operations, Inc., 2010. Original data: Consolidated Lists of Civil War Draft Registrations, 1863-1865. NM-65, entry 172, 620 volumes. NAI: 4213514. Records of the Provost Marshal General's Bureau (Civil War), Record Group 110. National Archives at Washington D.C 32178_645874_0062-00286.

19 Pennsylvania, Philadelphia City Births, 1860-1906.

20 "United States Census, 1870," database with images, FamilySearch (https://familysearch.org/ ark:/61903/3:1:S3HY-6WJ7-H1X?cc=1438024\&wc=92KW-829\%3A518666601\%2C519997601\% 2C520051401 : 22 May 2014), Pennsylvania > Philadelphia > Philadelphia, ward $20>$ image 1207 of 2859; citing NARA microfilm publication M593 (Washington, D.C.: National Archives and Records Administration, n.d.). 
21 Death Certificate: Pennsylvania, Philadelphia City Death Certificates, 1803-1915," database with images, FamilySearch (https://familysearch.org/ark:/61903/1:1:JKQ1-5WG : 9 December 2014), Matilda Duckett, 02 Nov 1871; citing item 1, Philadelphia City Archives and Historical Society of Pennsylvania, Philadelphia; FHL microfilm 2,020,949; Will: Ancestry.com. Pennsylvania, Wills and Probate Records, 1683-1993 [database on-line]. Provo, UT: Ancestry.com Operations, Inc., 2015. Original data: Pennsylvania County, District and Probate Courts Image 226.

22 Gopsill's Philadelphia City Directory for 1874. Isaac Costa, ed. (Philadelphia: James Gopsill, 1874), 421. Ancestry.com. U.S. City Directories, 1822-1995 [database on-line]. Provo, UT: Ancestry. com Operations, Inc., 2011.

23 "United States Census, 1880," database with images, FamilySearch (https://familysearch.org/ ark:/61903/1:1:MNZP-4DG : 29 August 2017), William Duckett in household of Harry Sellers, Camden, Camden, New Jersey, United States; citing enumeration district ED 44, sheet 141D, NARA microfilm publication T9 (Washington D.C.: National Archives and Records Administration, n.d.), roll 0773; FHL microfilm 1,254,773; United States Census, 1880," database with images, FamilySearch (https:/familysearch.org/ark:/61903/1:1:MNZ5-VWF : 12 August 2017), William H Duckett in household of Joseph C Ellis, Ellisburg, Camden, New Jersey, United States; citing enumeration district ED 59, sheet 458D, NARA microfilm publication T9 (Washington D.C.: National Archives and Records Administration, n.d.), roll 0774; FHL microfilm 1,254,774.

24 Pennsylvania, Philadelphia City Death Certificates, 1803-1915," database with images, FamilySearch (https://familysearch.org/ark:/61903/1:1:JKQM-VPX : 9 December 2014), William H. Duckett, 07 Jul 1880; citing, Philadelphia City Archives and Historical Society of Pennsylvania, Philadelphia; FHL microfilm 2,047,203.

25 William White, "Billy Duckett: Whitman Rogue," American Book Collector 21 (February 1971), 20-23. Allen mistakenly writes that it was Duckett's mother, not his grandmother, who had recently died prior to his boarding at Mickle Street (Solitary Singer, 523).

26 Geoffrey Sill, "Mickle Street House [Camden, New Jersey]" from The Walt Whitman Encyclopedia, available on the Walt Whitman Archive.

27 Howe's Camden City \& County Directory (Philadelphia: C. E. Howe Co, 1884), 520. Ancestry. com. U.S. City Directories, 1822-1995 [database on-line]. Provo, UT: Ancestry.com Operations, Inc., 2011.

28 See "Racing News," The Bicycling World 13.11 (July 16, 1886), 292; "Sea Isle City," The (Camden) Morning Post, (July 9, 1886), 2.

29 See "The Path," The Cycle 1 (June 11, 1886), 205.

30 “Races at Merchantville," Camden Daily Courier 5 (June 21, 1886), 1.

31 "Rinkles from the Rinks," The Morning Post (March 2, 1885), 1.

32 Walt Whitman Papers in the Charles E. Feinberg Collection: Supplementary File, 1806-1981; Speeches and Writings File, 1866-1978; Articles and other writings; Duckett, William H., diary notes, 1886-1887, with introductory note by Whitman; mss18630, box 74 .

33 John Browning, quoted in "Life Hereabouts," by Charley Humes Courier-Post (June 1, 1950), 2.

$34 W W C, 4: 65$

35 “Sea Isle City," Courier-Post (July 9, 1886), 2. 
36 Elizabeth L. Keller, Walt Whitman in Mickle Street (New York: Mitchell Kennerley, 1921), 6970 .

37 “An Old Poet's Reception," The Evening Sun, (April 15, 1887), WWA ID: med.00558.

$38 W W C, 4: 65$.

$39 D B N, 2: 382 ; 2: 384$.

40 White, 22.

41 Letter from Walt Whitman to Richard Maurice Bucke, January 31, 1889. WWA ID: loc.07574.

42 Letter from Bill Duckett to Richard Maurice Bucke, December 27, 1886. Walt Whitman Papers in the Charles E. Feinberg Collection: Supplementary File, 1806-1981; Speeches and Writings File, 1866-1978; Articles and other writings; Duckett, William H., diary notes, 1886-1887, with introductory note by Whitman; mss18630, box 74 .

43 Howe's Camden City Eீ County Directory (Philadelphia: C. E. Howe Co, 1884), 520. Ancestry. com. U.S. City Directories, 1822-1995 [database on-line]. Provo, UT: Ancestry.com Operations, Inc., 2011.

44 For Whitman's note about paying $\$ 16$, see $D B N 2: 400$. For his mention of the $\$ 10$, see $D B N$ 2:511.

45 “Personals Column," Camden Daily Telegram (March 20, 1888), 1.

46 Walt Whitman to the Philadelphia Press, June 2, 1886, WWA ID: loc.03500.

47 See Charles M. Oliver, Critical Companion to Walt Whitman (New York: Facts on File, 2006), 279; White, 21.

$48 D B N, 2: 390 ; 396$.

49 See $D B N, 2: 410 ; 414 ; 429 ; 432$; see also 349n1907.

50 DBN, 3:429. See "William H. Duckett" in Howe's Camden City and County Directory (18881889), 717. Ancestry.com. U.S. City Directories, 1822-1995 [database on-line]. Provo, UT: Ancestry. com Operations, Inc., 2011; Howe's Camden City Directory (1887-1888), 216. Ancestry.com. U.S. City Directories, 1822-1995 [database on-line]. Provo, UT: Ancestry.com Operations, Inc., 2011.

51 Walt Whitman Papers in the Charles E. Feinberg Collection: General Correspondence, 18411892; Duckett, William H., undated, series: General Correspondence, 1841-1892. Mss18630, box 9; reel 5-6.

$52 D B N, 2: 357$.

53 Richard Maurice Bucke, Calamus: A Series of Letters written during the years 1868-1880 (Boston: L. Maynard, 1897), 32-33.

$54 W W C, 6: 79$.

55 F. DeWolfe Miller, "New Glimpses of Walt Whitman in 1886," Tennessee Studies in Literature 8 (1963), 71-80; $W W C, 4: 66$.

56 Miller, 78-79.

57 Whitman's handwritten notes are included in the file with Duckett's diary notes in the Feinberg Collection. Walt Whitman Papers in the Charles E. Feinberg Collection: Supplementary File, 1806- 
1981; Speeches and Writings File, 1866-1978; Articles and other writings; Duckett, William H., diary notes, 1886-1887, with introductory note by Whitman, series: Supplementary File, 1806-1981, mss18630, box 74 .

58 See Folsom, "Whitman’s Calamus Photographs,” in Breaking Bounds, 211-212.

59 William's Cincinnati Directory (Cincinnati: Directory Office, 1893), 438. Ancestry.com. U.S. City Directories, 1822-1995 [database on-line]. Provo, UT: Ancestry.com Operations, Inc., 2011.

60 The Charlotte Observer (April 12, 1895), 4.

61 Daily Concord Standard (April 18, 1895), 3.

62 The Charlotte Observer (August 12, 1888), 4.

63 M. M. McEwen, First United Methodist Church, Charlotte, North Carolina (Charlotte, NC: Heritage Printers, 1983), 35.

64 "And They Were Wed," The Charlotte Observer (June 4, 1895), 4. Charles and Annie were married over forty years and had two daughters, Lucille and Helen. Charles, a Charlotte cafe owner, died in 1936, survived by Annie who died in 1962.

65 Ancestry.com. North Carolina, Marriage Records, 1741-2011 [database on-line]. Provo, UT: Ancestry.com Operations, Inc., 2015. Original data: North Carolina County Registers of Deeds. Microfilm. Record Group 048. North Carolina State Archives, Raleigh, NC 42091_333005-00746.

66 "To Celebrate the Fourth," The Charlotte Observer (July 4, 1895), 4.

67 "Blacksmithing," The Charlotte Democrat (January 18, 1870), 1.

68 “A July Wedding," The Charlotte Observer (July 3, 1895), 2.

69 Ancestry.com. North Carolina, Marriage Records, 1741-2011 [database on-line]. Provo, UT: Ancestry.com Operations, Inc., 2015. Original data: North Carolina County Registers of Deeds. Microfilm. Record Group 048. North Carolina State Archives, Raleigh, NC 42091_333005-00746.

70 "To Celebrate the Fourth," The Charlotte Observer (July 4, 1895), 4.

71 Sarah's Death: The Charlotte Observer (May 2, 1896), 4. Robert's Birth: Ancestry.com. North Carolina, Death Certificates, 1909-1976 [database on-line]. Provo, UT: Ancestry.com Operations Inc., 2007. Original data: North Carolina State Board of Health, Bureau of Vital Statistics. North Carolina Death Certificates. Microfilm S.123. Rolls 19-242, 280, 313-682, 1040-1297. North Carolina State Archives, Raleigh, North Carolina.

72 “Ring the Old Year Out," Mecklenburg Times (December 31, 1896), 8.

73 Superior Court of North Carolina, Mecklenburg County. E. Adelaide Duckett vs. William H. Duckett, December 6, 1900. Jane Johnson, manager of the Robinson-Spangler Carolina Room and Meghan Bowden, library aide, were kind enough to provide us with scans of the divorce documents that are held in the collections of the Charlotte Mecklenburg library.

74 Ancestry.com. U.S., Spanish American War Volunteers Index to Compiled Military Service Records, 1898. Provo, UT,: Ancestry.com Operations, Inc., 2012.

75 "United States Index to Service Records, War with Spain, 1898", database with images, FamilySearch (https://familysearch.org/ark:/61903/1:1:2HXF-B69 : 17 June 2015), William H. Duckett, 1898; Roster of the North Carolina Volunteers in the Spanish-American War 1898-1899 
(Raleigh: Edwards \& Broughton and E. M. Uzzell, State Printers, 1900), 64.

76 Year: 1900; Census Place: Charlotte Ward 3, Mecklenburg, North Carolina; Page: 1; Enumeration District: 0047. Ancestry.com. 1900 United States Federal Census. Provo, UT: Ancestry.com Operations Inc., 2004.

77 Superior Court of North Carolina, Mecklenburg County. E. Adelaide Duckett vs. William H. Duckett, December 6, 1900.

78 The Charlotte News (March 28, 1901), 1.

79 The Charlotte Observer (December 27, 1901), 6.

80 "Shelor \& Company," News and Observer (December 15, 1906), 3.

81 The Charlotte Observer (October 9, 1904), 15.

82 The Charlotte News (December 14, 1904), 10; The Charlotte News (December 9, 1905), 9.

83 The Philadelphia Inquirer (May 24, 1904), 14.

84 Wills and Estate Papers (Mecklenburg County), 1663-1978; Author: North Carolina. Division of Archives and History (Raleigh, North Carolina); Probate Place: Mecklenburg, North Carolina; Ancestry.com. North Carolina, Wills and Probate Records, 1665-1998. Provo, UT: Ancestry.com Operations, Inc., 2015. Original data: North Carolina County, District and Probate Courts.

85 The Charlotte News (June 4, 1904), 5.

86 Pennsylvania State Reports, vol. 214. William I. Schaffer, reporter (The Banks Law Publishing Company, 1906), 362-368.

87 The death certificate lists Duckett's age as “about 35 years." The Philadelphia Inquirer (September 22, 1902), 7. Inquirer (September 24, 1902), 15. See also "Died of Alcoholism," Miners fournal (September 24, 1902), 3.

88 Internment Record: Historical Society of Pennsylvania; Philadelphia, Pennsylvania; Historic Pennsylvania Church and Town Records; Ancestry.com. Pennsylvania and New Jersey, Church and Town Records, 1669-2013 [database on-line]. Lehi, UT: Ancestry.com Operations, Inc., 2011; Death certificate: Ancestry.com. Philadelphia, Pennsylvania, Death Certificates Index, 1803-1915. Provo, UT: Ancestry.com Operations, Inc., 2011. "Pennsylvania, Philadelphia City Death Certificates, 1803-1915." Index. FamilySearch, Salt Lake City, Utah, 2008, 2010. From originals housed at the Philadelphia City Archives. "Death Records."

89 The Philadelphia Inquirer (September 3, 1917), 11.

90 The Charlotte News (July 16, 1917), 2.

91 The Charlotte News (October 12, 1917), 13.

92 News and Observer (August 4, 1918), 13.

93 Specimen Days E Collect (Philadelphia, David McKay, 1882), 80.

94 Ancestry.com. North Carolina, Marriage Records, 1741-2011. Provo, UT: Ancestry.com Operations, Inc., 2015.

95 Greensboro Daily News (May 2, 1929). 
96 Ancestry.com. U.S., Social Security Applications and Claims Index, 1936-2007. Provo, UT: Ancestry.com Operations, Inc., 2015.

97 Nezws and Observer (February 10, 1937); News and Observer (June 22, 1938); Genealogybank. com.

98 The High Point (NC) Enterprise (December 16, 1965), 53.

99 North Carolina State Archives; Raleigh, North Carolina; North Carolina Death Certificates. Ancestry.com. North Carolina, Death Certificates, 1909-1976. Provo, UT: Ancestry.com Operations Inc., 2007.

100 First Marriage: May 29, 1959 Source Information Ancestry.com. North Carolina, Marriage Records, 1741-2011. Provo, UT: Ancestry.com Operations, Inc., 2015. Original data: North Carolina County Registers of Deeds. Microfilm. Record Group 048. North Carolina State Archives, Raleigh, NC 42091_343420-02679; Second Marriage: December 6, 1963 Source Information Ancestry.com. North Carolina, Marriage Records, 1741-2011. Provo, UT: Ancestry.com Operations, Inc., 2015. Original data: North Carolina County Registers of Deeds. Microfilm. Record Group 048. North Carolina State Archives, Raleigh, NC 42091_343394-01253.

101 Loving describes Duckett as "a sailor who was an acquaintance of Mrs. Davis's" (Song of Himself, 450). Duckett seems to be partially confused here with Frank Warren Fritzinger, or "Warrie" as Whitman affectionately referred him. Fritzinger was the son of a sea captain and had gone to sea by the age of 13 (1880 census). Duckett's occupation, however, is consistently listed in relation to telegraphy. There does not seem to be definitive evidence that Duckett ever went to sea.

$102 W W C, 1: 66$. 